\title{
Ras-Interacting Protein 1
}

National Cancer Institute

\section{Source}

National Cancer Institute. Ras-Interacting Protein 1. NCI Thesaurus. Code C98186.

Ras-interacting protein 1 (963 aa, 103 kDa) is encoded by the human RASIP1 gene. This protein is involved in signal transduction. 